\title{
EDUKASI TEOLOGI DALAM KELUARGA KRISTEN SEBAGAI PONDASI PREVENTIF RADIKALISME
}

\author{
Ibelala Gea ${ }^{1}$ \\ ${ }^{1}$ Dosen Fakultas Teologi IAKN Tarutung \\ pakgea.iakn@gmail.com
}

\begin{abstract}
One of the factors in the emergence of radicalism is the misinterpretation of the Scriptures and the weak theological education in the family. Parents as the primary and first educators in fact tend to leave their assignments to other parties who do not necessarily educate their children properly. The impact of this bad and incorrect theological education tends to form a mindset of exclusivism and rejecting inclusivism that creates intolerant people, considers all who do not have the same opinion and belief as the address of violence that must be eradicated. The family, both in the Old and New Testament times, in this case the parents, has the obligation and responsibility to educate children to understand the essence of God properly and correctly to His people. This article uses the mix methods method by collecting data on 30 (thirty) members of the Whatsapp Group STM Marsiurupan Sipoholon District which aims to describe 5 (five) theological educational content in Christian families as a preventive foundation for radicalism, especially radicalism in the name of religion in a descriptive qualitative method. 5 (five) theological educational contents are (1) Educating children to understand the Scriptures properly and correctly; (2) Understanding the essence of One God; (3) Understanding the essence of God as a savior, (4) Understanding the essence of God as a preserver; and (5) Understanding the essence of God as loving and compassionate.
\end{abstract}

\begin{abstract}
ABSTRAK
Salah satu faktor timbulnya radikalisme adalah kesalahan interpretasi terhadap Kitab Suci serta lemahnya edukasi teologi dalam keluarga. Para orangtua sebagai edukator utama dan pertama justru cenderung menyerahkan tugas mereka kepada pihak lain yang belum tentu mengedukasi anak dengan baik dan benar. Dampak edukasi teologi yang tidak baik dan benar ini cenderung membentuk mindset eklusivisme dan menolak inklusivisme yang melahirkan insan intoleran, menganggap semua yang tidak sepaham dan sekeyakinan sebagai alamat kekerasan yang harus dimusnahkan. Keluarga, baik pada zaman Perjanjian Lama maupun Perjanjian Baru, dalam hal ini para orangtua, memiliki kewajiban serta tanggungjawab mengedukasi anak agar memahami hakikat Tuhan dengan baik dan benar kepada umat-Nya. Artikel ini menggunakan metode mix methods dengan pengumpulan data terhadap 30 (tiga puluh) orang anggota Whatsapp Group STM Marsiurupan Kecamatan Sipoholon yang bertujuan untuk menjabarkan 5 (lima) konten edukasi teologi dalam keluarga Kristen sebagai pondasi preventif radikalisme, utamanya radikalisme yang mengatasnamakan agama secara deskriptif kualitatif. 5 (lima) konten edukasi teologi tersebut ialah (1) Mengedukasi anak memahami Kitab suci dengan baik dan benar; (2) Memahami hakikat Tuhan yang Esa; (3) Memahami hakikat Tuhan sebagai penyelamat, (4) Memahami hakikat Tuhan sebagai pemelihara; dan (5) Memahami hakikat Tuhan sebagai pengasih dan penyayang.
\end{abstract}

\section{PENDAHULUAN}

With gun you can kill radicalist, with education you can kill radicalism. Kalimat ini menggambarkan bahwa tidak selamanya radikalisme dapat ditumpas dengan senjata, melainkan dapat dihalau dengan edukasi yang benar. Bentuk radikalisme yang paling mudah diserap oleh berbagai kalangan ialah radikalisme agama karena seyogyanya hampir seluruh manusia, secara khusus di Indonesia, pasti memiliki agama. Kata radikalisme berasal dari bahasa Latin: radix yang berarti akar dan radicalis yang 
berarti berakar, mengakar atau memiliki akar ${ }^{1}$. Pada satu sisi, agama mengajarkan kebaikan dan mendatangkan rahmat dan berkat bagi umat manusia. Namun di sisi lain, agama juga memiliki daya rusak dan dapat menimbulkan kehancuran ${ }^{2}$. Hal ini disebabkan karena para pengikut agama tersebut akan berusaha agar aturan dan ajaran agama merekalah yang dijadikan sebagai pedoman bagi semua orang.

Radikalisme yang mengatasnamakan agama cenderung dijumpai pada seluruh pemeluk agama. Secara garis besar, dikenal kelompok radikalisme di kalangan Islam di Indonesia, di antaranya: Front Pembela Islam (FPI) pimpinan Habib Rizieq Shihab, Laskar Jihad pimpinan Ja'far Umar Thalib, Majelis Mujahidin pimpinan Abu Bakar Ba'asyir, Ikhwanul Muslimin pimpinan Habieb Husein al-Habsyi, Hizbut Tahrir Indonesia (HTI) pimpinan Hafidz Abdurahman dan lain-lain. Sedangkan di kelompok Kristen, di antaranya Army of God dan Ku Klux Klan di Amerika serikat, The Lords Resistance Army di Urganda, The National Liberation Front of Tripura di India bahkan di Indonesia dikenal Laskar Kritus Pasukan Kelelawar di Poso sekitar tahun 1990. Pemerintah Indonesia sangat concern dalam mencegah dan menanggulangi gerakan radikalisme. Hal ini terbukti dengan penerbitan Peraturan Presiden Nomor 7 Tahun 2021 tentang Rencana Aksi Nasional Pencegahan dan Penanggulangan Ekstremisme Berbasis Kekerasan yang Mengarah pada Terorisme ${ }^{3}$.

Contoh nyata kekerasan yang mengatasnamakan doktrin agama di Indonesia di antaranya peristiwa satu keluarga yang terdiri dari empat orang di Dusun Lepanu, Desa Lemban Tongoa, Kecamatan Palolo, Kabupaten Sigi, Sulawesi Tengah tewas dibunuh oleh kelompok teroris pada 27 November $2020^{4}$ yang sampai sekarang belum ditemukan pelakunya. Aksi kekerasan tersebut diduga dilakukan oleh kelompok sipil bersenjata Mujahidin Indonesia Timur (MIT) Poso, pimpinan Ali Kalora ${ }^{5}$. Salah satu karakteristik inti ajaran teologi MIT adalah tauhid sebagai landasan hidup dan syariat Islam sebagai tatanan dalam semua aspek kehidupan ${ }^{6}$. Dengan demikian, semua kelompok yang tidak sealiran dengan mereka dianggap sebagai kafir serta cenderung dijadikan sebagai alamat tindakan kekerasan. Selain kejadian di atas, aksi teror bom bunuh diri sebagai buah dari radikalisme kembali terjadi di halaman gereja katholik Makassar pada Minggu, 28 Maret 2021 dan aksi teror di Markas Besar Kepolisian Republik Indonesia oleh seorang wanita pada Rabu, 31 Maret 2021 menyiratkan bahwa radikalisme agama masih eksis di Indonesia. Peristiwa-peristiwa di atas hanyalah sebagian contoh dari wujud radikalisme agama yang sudah mengakar di Indonesia.

Segala hal yang berkaitan dengan agama pertama kali diterima dari keluarga sebagai tempat utama terbentuknya karakter manusia yang berperan penting dalam pengenalan pengetahuan tentang Tuhan termasuk di dalamnya etika, moral, kasih, kebaikan bahkan kejahatan, kekerasan dan sebagainya. Dalam kekristenan, dikenal pembinaan pranikah di mana salah satu kontennya adalah mengedukasi para calon suami-isteri dalam mempersiapkan diri menjadi calon ayah dan ibu dalam keluarga. Tindak lanjut edukasi ini semakin diperkuat ketika mereka menyerahkan anak-anaknya menerima baptisan kudus di gereja. Secara tradisi, para pelayan akan mengingatkan kembali tentang tugas sebagai orangtua untuk mengedukasi anak dalam mengenal dan mempercayai Tuhan sepanjang hayat. Edukasi ini dapat dikatakan sebagai wejangan bahwa janganlah seorang laki-laki dan perempuan menjadi suami-isteri sebelum mampu memahami bagaimana mengedukasi anak-anak dalam memahami kebenaran yang dijadikan pedoman

\footnotetext{
${ }^{1}$ Angel Damayanti, Radikalisme Pada Komunitas Non-Islam, Repository Universitas Kristen Indonesia, 2018, hal. 2

${ }^{2}$ Ibid, hal. 3-4

${ }^{3}$ Surat Kabar Sinar Indonesia Baru (SIB) terbit Senin, 18 Januari 2021, hal.1

${ }^{4}$ www.republika.co.id/berita/qklu9t328/insiden-sigi-serangan-serius-terhadap-kebebasan-beragama

${ }^{5}$ www.pikiran-rakyat.com/nasional/pr-011031748/kelompok-mit-diduga-dalang-teror-di-sigi-satgas-tinombalatolonglah-masyarakat-jangan-bantu-mereka

${ }^{6}$ www.majelismujahidin.com/about/karakteristik-majelis-mujahidin
} 
mereka untuk bersosialisasi di tengah masyarakat yang heterogen. Tradisi umat Israel menjadikan kaum bapa menjadi edukator utama terhadap anak-anak dalam rumah tangga (Kel 6:4-9). Tugas mereka memberi edukasi yang baik. Orangtua selain memiliki kemampuan kognitif juga harus menyediakan waktu dan penuh kesungguhan dalam mengedukasi anak-anak dengan kesabaran, bukan hanya teori, tetapi lebih pada keteladanan.

Radikalisme agama cenderung dilatarbelakangi oleh kesalahan peletakan pondasi konten edukasi teologi di lingkungan masing-masing umat beragama terutama dalam keluarga dengan orientasi melakukan pembaharuan secara mendasar terhadap ideologi dan sistem pemerintahan pada sebuah negara. Ibarat membangun rumah harus didasari dengan pondasi yang kokoh agar tidak runtuh diterpa berbagai gangguan. Sumber utama teologi pada umumnya adalah Kitab Suci di mana pendekatan edukasi teologi dalam memahami Kitab Suci pada umumnya hampir semua agama masih pada tataran penekanan tekstual literal dengan metode menghapal ayat-ayat Kitab Suci yang membentuk keyakinan dan perilaku yang cenderung mengabaikan interpretasi konteks historis, sosiologis, psikolologs, politik dan ekonomi dari sebuah Kitab Suci. Pendekatan edukasi teologi seperti itu cenderung menciptakan kedangkalan pemahaman teks-teks Kitab Suci karena tanpa interpretasi yang baik dan benar akan mendorong lahirnya sikap eksklusivisme, mengabaikan inklusivisme dan pluralisme di antara para penganut agama. Pada hakikatnya, Tuhan Yang Maha Esa Pencipta Langit dan Bumi mengasihi seluruh ciptaan-Nya. Namun, akibat kedangkalan pemahaman seseorang atau kelompok tentang fakta pribadi Allah ${ }^{7}$, maka mereka menganggap bahwa hanya Allah yang diyakini oleh agamanya yang benar serta patut menjadi pedoman dalam kehidupan berbangsa dan bernegara. Kecenderungan pengetahuan yang dangkal dan edukasi teologi yang eksklusivisme menjadi salah satu embrio penanaman nilai-nilai intoleransi dan kekerasan yang mengakar pada mindset dan perilaku penganut agama, di mana pada saatnya membentuk pemikiran dan keyakinan yang tidak kenal kompromi, menganggap agama dan teologinya sebagai satu-satunya kebenaran, yang lain adalah salah bahkan sesat dan harus dimusnahkan. Pengetahuan tentang dasar-dasar teologi harus diajarkan secara seimbang, bukan hanya mengenal dan memahami tentang Tuhan secara teosentris, tetapi juga secara humanis, yakni adanya pemahaman penerapan keyakinan secara vertikal dan horizontal.

Sekaitan dengan uraian di atas, edukasi teologi dalam keluarga Kristen seharusnya menjadi pusat pondasi edukasi teologi yang berfungsi sebagai langkah preventif terhadap radikalisme dalam cakupan yang lebih luas. Demikian juga edukasi tentang etika dan moral yang baik dan benar dengan peran meletakkan pondasi pengetahuan dan pemahaman tentang hakikat Tuhan melalui pengenalan Kitab Suci. Sedangkan institusi pendidikan, baik formal dan nonformal, sesungguhnya bukan mengambil alih atau menggantikan tugas pokok keluarga, melainkan meneruskan sembari meluruskan serta mengembangkan pondasi pengetahuan yang telah diletakkan dalam keluarga masing-masing insan pemeluk agama. Pada akhirnya, keluarga harus mengubah pola pikir yang selama ini cenderung menyerahkan sepenuhnya edukasi anakanak mereka kepada yang lain, terutama edukasi keagamaan. Edukasi keluarga memegang peranan penting secara khusus di bidang agama maupun teologi. Jika pengenalan dan pemahaman isi Kitab Suci serta teologi dasar disajikan dengan baik dan benar dalam keluarga, maka dapat menolong para generasi penerus untuk hidup berdampingan, menghargai, menghormati, menerima perbedaan-perbedaan pada komunitas lain dan sebaliknya. Dengan demikian, keluarga secara bertanggungjawab sesuai dengan panggilannya harus meletakkan pondasi yang baik dan benar berdasarkan pemahaman Kitab Suci terhadap paham radikalisme.

${ }^{7}$ Charles C.Ryrie, Teologi Dasar: Panduan Populer Untuk Memahami Kebenaran Alkitab, (Yogyakarta : Yayasan Andi), 2010, hal.43 


\section{METODE PENELITIAN}

Artikel ini bertujuan untuk menjabarkan edukasi teologi dalam keluarga Kristen sebagai pondasi preventif terhadap radikalisme dengan menggunakan metode mix methods. Menurut Sugiyono (2011:18), mix methods adalah metode penelitian dengan mengombinasikan antara 2 (dua) metode penelitian sekaligus, kualitatif dan kuantitatif dalam suatu kegiatan penelitian sehingga diperoleh data yang lebih komprehensif, valid, reliabel dan objektif. Penulis melakukan mini riset melalui pengumpulan data terhadap 30 (tiga puluh) orang informan (anggota grup Whatsapp) sebuah komunitas masyarakat, yaitu Serikat Tolong Menolong (STM) Marsiurupan yang berlokasi di Jalan Raya Balige Km 2, Kec. Sipoholon, Kab. Tapanuli Utara. Komunitas ini telah berdiri lebih 30 (tiga puluh) tahun dan tetap eksis sampai sekarang. Anggota STM Marsiurupan menganut agama Kristen serta anak-anak mereka telah mengecap pendidikan dengan baik juga banyak dari mereka merantau di berbagai wilayah Nusantara serta mampu hidup bermasyarakat dengan baik.

Dari berbagai referensi serta hasil pengumpulan data melalui pertanyaan singkat dalam grup Whatsapp, 30 (tiga puluh) orang informan menyatakan edukasi teologi dalam keluarga sebagai pondasi preventif terhadap radikalisme sangat diperlukan dan penting dengan konten pokok sebagai berikut:

1. Sebagai keluarga Kristen wajib membaca Alkitab setiap hari

2. Tuhan yang disembah orang Kristen adalah Allah Bapa, Anak dan Roh Kudus sama dengan Tuhan Yang Maha Esa berdasarkan Ulangan 6:4 dan 1 Timotius 2:5

3. Sebagai keluarga Kristen, Tuhan tetap memelihara umat-Nya sekalipun kejahatan semakin merajalela

4. Sebagai keluarga Kristen yang telah diselamatkan oleh Yesus Kristus, wajib memberitakan keselamatan itu kepada orang lain

5. Sebagai keluarga Kristen yang telah menerima kasih Tuhan, wajib mengasihi orang lain Berdasarkan hasil pengumpulan data di atas, maka penulis menjabarkan secara deskriptif kualitatif 5 (lima) poin penting edukasi teologi dalam keluarga Kristen sebagai pondasi preventif terhadap radikalisme yang dijabarkan pada bagian pembahasan dalam artikel ini.

\section{PEMBAHASAN}

Artikel ini menitikberatkan edukasi bidang teologi yang bersumber dari Kitab Suci. Jika teologi

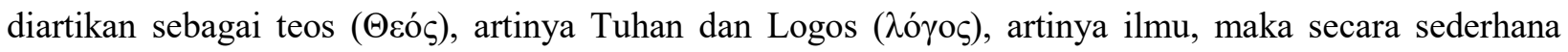
teologi diartikan sebagai ilmu yang membicarakan tentang Tuhan. Namun lebih dari itu, teologi adalah segala sesuatu yang berkaitan dengan Allah $^{8}$, dapat diartikan bahwa teologi sebagai ilmu yang mempelajari mengenai Allah, menyangkut hakikat, sifat, karya-Nya, rencana-Nya serta respon manusia terhadap Firman-Nya ${ }^{9}$ yang bersumber dari Wahyu Ilahi bernama Kitab Suci. Itulah sebabnya teologi dalam arti luas adalah studi tentang keberadaan Allah, eksistensi pribadi-Nya, menyangkut karya-Nya dan rencana-Nya untuk dipahami oleh orang percaya sebagai pedoman atau kompas kehidupan ${ }^{10}$. Edukasi teologi dalam keluarga Kristen meliputi bagaimana secara praktis para orangtua memperkenalkan anak dalam memahami siapakah Tuhan, sifat-Nya, karya-Nya, rencana-Nya kepada seluruh ciptaan-Nya. Teologi dapat dikatakan

${ }^{8}$ Leon Morris, Teologi Perjanjian Baru, (Malang: Gandum Mas), 2014, hal. 10

${ }^{9}$ Ibelala Gea, Implementasi Pembaharuan Pelaksanaan Pesta Perkawinan Adat Suku Nias Berbasis Teologi Kristen, (Disertasi), 2020, hal. 78

${ }^{10}$ Erastus Sabdono dalam Bunga Rampai Moving To The Next Level: Akselarasi Mutu Perguruan Tinggi Keagamaan Kristen di Indonesia, Rehobot Ministry bersama dengan BMPTKKI dan Ditjen Bimas Kristen RI, 2014, hal. 87 
sebagai hasil interpretasi yang rasional tentang iman keagamaan ${ }^{11}$. Oleh karena luas dan kompleksnya konten edukasi teologi dimaksud, maka artikel ini fokus pada pondasi representatif yang dapat menjadi preventif radikalisme sebagai berikut:

\section{Mengedukasi Anak Memahami Kitab Suci}

Membaca Kitab Suci, dalam hal ini Alkitab, secara teratur pada pagi dan malam hari pada ibadah keluarga adalah salah satu cara mengenal dan memahami Kitab Suci, termasuk menghapal ayat-ayat yang menjadi kunci pada setiap bacaan. Akan tetapi, sebagai orangtua yang beriman dan telah belajar Kitab Suci dengan benar perlu mempunyai modal dalam memahami apa arti dan tujuan dari isi kitab Suci yang telah dibaca serta pesan yang harus dilakukan dan dihindari menurut kehendak Tuhan kepada manusia dan ciptaan lainnya. Tuhan Yesus mengecam orang Saduki yang tidak memahami atau mengerti Kitab Suci secara baik dan benar sekaitan pengajaran Yesus tentang adanya kebangkitan orang mati (Mat 22:15-22; Mrk 12:18-27; Luk 20:27-40). Tuhan Yesus mengajarkan umat-Nya untuk memahami Kitab Suci bukan hanya secara tekstual atau literal, melainkan mampu menginterpretasinya dengan baik. Kitab Suci Kristen yang dikenal dengan sebutan Alkitab, terdiri dari 39 kitab Perjanjian Lama dan 27 kitab Perjanjian Baru tentu bukan diturunkan dan didiktekan oleh Allah dari Sorga, melainkan disampaikan melalui orang-orang pilihan-Nya seperti nabi, rasul dan pihak lain sebagai penulis Kitab Suci yang telah diilhami oleh Allah (2 Tim 2:16). Isi Alkitab bukan pula oleh keinginan manusia, melainkan oleh dorongan Roh Kudus yang berbicara atas nama Allah (2 Pet 1:21). Oleh karena itu, orang-orang yang menulis Kitab Suci diberi inspirasi dan iluminasi agar mereka menulis tentang kebenaran Allah dengan baik dan benar. Sekaitan dengan hal ini, umat Kristen harus terhindar dari pemahaman Kitab Susi dengan hanya menghapal ayatayat tertentu, khususnya ayat yang cenderung membentuk mindset eklusivisme dan intoleransi. Orangtua sebagai edukator utama dan pertama wajib memberi edukasi tentang Firman Allah dan menyampaikannya kepada anak dalam keluarga dengan menanamkan mindset ekslusivisme serta toleransi agar tercipta pemahaman yang baik dan benar tentang hakikat Alkitab. Dengan demikian, hal itu dapat menolong para penganut agama jauh dari pola pikir radikalisme.

\section{Mengedukasi Anak Memahami Hakikat Tuhan Adalah Esa}

Sekian banyak hakikat dan sifat Allah, keesaan menjadi sentral pengajaran dalam Alkitab, khususnya dalam Perjanjian Lama di mana umat Israel menganut monoteisme dan menolak keras politeisme. Edukasi tentang keesaan Allah menjadi pondasi utama dalam keyakinan Israel. Ketika Musa menyuruh mereka yang diawali kalimat "Dengarlah, hai orang Israel atau schema Yisrael, Yahwe Elohenu, Yahwe Ekhad, artinya dengarlah Israel, Yahwe itu Allah kita, Yahwe itu Esa" (Ul 6:4). Dalam terjemahan Indonesia, "TUHAN itu Allah kita, Tuhan itu Esa, Kasihilah Tuhan Allahmu dengan segenap hatimu dan dengan segenap jiwamu dan dengan segnap kekuatanmu" (U1 6:4-5). Perjanjian Baru juga turut mendukung hakikat Allah yang esa. Pada umumnya, terdapat kecenderungan para penganut agama di luar Kristen memahami bahwa orang Kristen menyembah 3 (tiga) Allah dan bukan esa. Hal itu disebabkan karena doktrin Kristen menyebut tiga pribadi yang berbeda, yakni Allah Bapa, Anak dan Roh Kudus (Mat 28:18-20). Namun, perlu dipahami bahwa Allah disapa sebagai Bapa karena Dia Pencipta, Pemilik, Pemelihara alam semesta; disapa sebagai Anak karena Dia Penyelamat seluruh ciptaan; dan disapa sebagai Roh Kudus karena Dia menyertai umatNya dimanapun karena kekuasaan-Nya tidak dibatasi oleh ruang dan waktu. Setiap orang yang telah menerima-Nya dan mengakui-Nya, mereka menyembah Allah yang tidak lagi terikat oleh tempat dan waktu, tetapi menyembah-Nya dalam Roh dan kebenaran (Yoh 4:24). Oleh sebab itu bahwa Bapa (Allah); Yesus adalah Sabda Firman; dan Roh Kudus (Roh Allah), ketiganya adalah Esa karena sezat, sehakikat

${ }^{11}$ Charles C.Ryrie, Teologi Dasar: Panduan Populer Untuk Memahami Kebenaran Alkitab, (Yogyakarta: Yayasan Andi), 2010, hal. 15 
serta tidak bisa dipisahkan dalam karya-Nya. Hanya ada satu Allah saja dan bahwa sifat dasar atau watak Allah tidak dapat dipisah-pisahkan atau dibagi ${ }^{12}$. Segala ilah dan bentuk penyembahan yang bukan memuliakan Allah yang Esa ditolak dari keluarga Kristen, hanya kepada Allah pencipta langit dan bumi yang telah menyatakan diri-Nya dalam Kristus Yesus yang layak dipuji dan disembah oleh manusia bersama ciptaan lainnya. Kata ekhad dalam bahasa Ibrani menuju pada kesatuan Bapa, Firman dan Roh Kudus. Demikian juga dalam kata Yunani Heis yang artinya satu. Donal Guthrie berupaya menjelaskan kesatuan itu yang terlihat dalam Yoh 1:1 mengenai logos bahwa Ia bukan hanya bersama-sama dengan Allah pada mulanya, tetapi Ia adalah Allah (theos en ho logos) ${ }^{13}$. Edukator dalam keluarga harus memastikan bahwa anak-anak mengenal dan memahami dengan baik dan benar bahwa alam semesta serta seluruh isinya adalah ciptaan Allah Yang Esa (Kej 1:1; Ul 6:4-5). Allah yang esa tersebut telah menyatakan diri-Nya dalam Yesus Kristus. Oleh sebab itu, Paulus menuliskan bahwa karena Allah itu esa dan esa pula Dia yang menjadi perantara antara Allah dan manusia, yaitu Kristus Yesus (1 Tim 2:5).

\section{Mengedukasi Anak Memahami Allah Sebagai Penyelamat}

Allah bukan hanya berkarya sebagai pencipta, tetapi juga sebagai penyelamat seluruh ciptaan-Nya. Setelah manusia jatuh dalam dosa, citra kesegambaran Allah (Imago Dei) dengan manusia telah rusak, tidak layak menjadi partner dan sekutu-Nya untuk mencerminkan kehendak Allah di bumi. Sebagai akibat kejatuhan itu, hati dan pikiran manusia cenderung memberontak terhadap Allah dan firman-Nya, segala bentuk kejahatan tertanam menjadi tabiat dalam diri manusia, yaitu ketidaktaatan kepada Allah, kebencian, iri hati bahkan roh pembunuhan terhadap sesamanya (Kej.1 :1-10). Akhirnya, manusia menjadi sekutu iblis beserta segala kehendaknya (Yoh 8:44). Harun Hadiwijono menyebutkan bahwa sebenarnya karena pemberontakan manusia sudah tidak layak lagi dihidupi sebab ia telah menginjak-injak perjanjian Tuhan Allah seperti halnya seorang anak yang telah memberontak kepada orang tuanya. Sekalipun demikian, Tuhan Allah berkenan masih mengikat diri-Nya kepada janji-Nya yang telah dikaitkan dengan kehendakNya menciptakan manusia. Demikanlah sejak semula telah ada hubungan antara Tuhan Allah dengan manusia dalam bentuk perjanjian kasih Karunia $^{14}$. Dapat dikatakan bahwa perjanjian kasih karunia Allah kepada manusia dilakukan-Nya secara sepihak sebagai inisiatif-Nya untuk menyelamatkan manusia dan ciptaan lainnya. Maka, sesungguhnya tidak ada daya manusia untuk menyelamatkan dirinya, kecuali bergantung pada kasih karunia Allah.

Kata ibrani "Khen" dan Yunani "Kharis" diterjemahkan dalam bahasa Indonesia sebagai kasih karunia. Perbuatan penyelamatan oleh kasih karunia itu dialami oleh Musa bersama umat Israel di tengah perjalanan di padang gurun (Kel 33:17). Rasul Paulus merespon kasih karunia itu dengan mengatakan telah menghidupkan kita bersama-sama dengan Kristus, sekalipun kita telah mati oleh kesalahan-kesalahan kita, oleh kasih karunia kamu diselamatkan dan di dalam Kristus Yesus Ia telah membangkitkan kita juga dan memberikan tempat bersama-sama dengan Dia di Sorga (Ef 2:5-7). Tindakan perjanjian kasih karunia Allah secara teologis berlangsung selama 4 (empat) kali dan selalu diperbaharui oleh Allah, yakni perjanjian-Nya dengan Nuh (Kej 9: 12-17), dengan Abraham (Kej 12:1-9), dengan umat Israel melalui Musa di Gunung Sinai (Kel 24:1-18), di dalam Perjanjian Baru terlihat perjanjian kasih karunia dan berkat kepada Abraham bukan hanya diterima oleh umat Israel sebagai keturunan Abraham secara lahiriah, melainkan kepada semua orang yang percaya kepada Allah melalui Yesus Kristus (Mat 8:10-12; 11:20-24;

\footnotetext{
${ }^{12}$ Dylfard Edward Pandey, Allah Tritunggal: Sebuah Risalah Teologis Alkitabiah tentang Keesaan dan Ketritunggalan Allah, Davar: Jurnal Teologi Vol. 1 No.1, 2020, hal. 47

${ }^{13}$ Donald Guthrie, Teologi Perjanjian Baru 1, (Jakarta: BPK Gunung Mulia), 2013, hal.383

${ }^{14}$ Harun Hadiwijono, Iman Kristen, (Jakarta: BPK Gunung Mulia), 2018, hal. 267
} 
Luk 10:33; 17:16-18). Demikian juga Paulus menyebutkan bahwa tidak semua orang yang berasal dari Israel adalah orang Israel (Rm 9:6-7), lebih jauh Paulus menjelaskan bahwa dalam hal ini tidak ada orang Yahudi atau orang Yunani, tidak ada hamba atau orang merdeka, tidak ada laki-laki atau perempuan karena kamu semua adalah satu di dalam Kristus Yesus. Dan jikalau kamu adalah milik Kristus, maka kamu juga adalah keturunan Abraham dan berhak menerima perjanjian Allah (Gal 3:28-29). Janji kasih karunia untuk menyelamatkan manusia secara sempurna telah digenapi oleh peristiwa reinkarnasi di mana Allah menjadi manusia dalam tubuh insani Yesus Kristus yang telah mati di kayu salib dan darah-Nya menjadi darah perjanjian tebusan dosa demi keselamatan manusia (Mat 26:28; Mark 14:24; Luk 22:20-24). Semua orang yang telah memperoleh kasih karunia keselamatan disebut sebagai sekutu dan partner Allah untuk menyatakan kehendak-Nya di tengah dunia yakni mewartakan kasih karunia, bukan membenci melainkan bermisi membawa damai.

\section{Mengedukasi Anak Memahami Allah Sebagai Pemelihara}

Edward Herbert yang berkebangsaan Inggris pada 1624 memunculkan ajaran deisme yang intinya bahwa Allah telah berhenti bekerja setelah Dia menciptakan segala sesuatu. Sebab itu, manusia harus menekankan peran akal dan kebenarannya ketika memahami kehidupan termasuk memahami peran Pencipta terhadap alam semesta. Itulah yang dialami di zaman pencerahan tersebut. Konsep deisme memerdekaan akal seluas-luasnya, tetapi cenderung mengabaikan pemeliharaan Allah yang berdaulat. Dalil deisme mencerahkan akal, yakni jika Allah terus bekerja memelihara seluruh ciptaan-Nya, tetapi mengapa di sana sini kejahatan merajalela, hukum rimba cenderung berlangsung, ketidakadilan, penindasan kepada yang tak berdaya, orang beriman teraniaya dan kekerasan hadir hampir setiap saat namun sepertinya Allah membisu dan tidak menghukum segala kejahatan. Sesungguhnya Allah tidak membisu dan berdiam diri, melainkan Dia terus bekerja memelihara ciptaan-Nya, sedangkan segala bentuk penderitaan dipakai-Nya mendidik umat-Nya untuk mempraktikkan iman dan menunjukkan ketaatan pada kehendak-Nya. Perjalanan Israel sebagai umat pilihan-Nya silih berganti mengalami berbagai penindasan, kesusahan, kelaparan meskipun diyakini bahwa Allah menjaga umat-Nya bagaikan biji mata (Ul 32:10; 11:12; Maz 17:8).

Demikian juga dalam Perjanjian Baru, Tuhan Yesus mengajarkan secara spesifik pemeliharaan Allah bagi ciptaan-Nya bahwa "Tidak seekor burung pipit pun yang dinilai kecil oleh manusia jatuh ke bumi di luar kehendak Bapa" (Mat 10:29). "Bapa di Sorga memberi makan kepada burung-burung tanpa mereka harus menabur benih, memetik atau menyimpan makanannya (Mat 6:26)"15. Apa yang terkandung dari ajaran Yesus hendak mengatakan pemeliharaaan Allah terhadap ciptaan-Nya terlebih kepada orang percaya tidak perlu diragukan. Kata pemeliharaan Allah dikenal dengan Providentia Dei. Dalam bahasa latin diartikan sebagai providere yang berarti tindakan Allah yang menyediakan segala sesuatu sebelum orang memikirkannya. Sebagaimana yang dialami oleh Abraham ketika Tuhan menyediakan seekor domba sebagai persembahan yang disembelih sebagai korban ganti Ishak (Kej 22:8, 14). Kata yang lain dalam bahasa Ibrani berkaitan dengan pemeliharaan adalah ra'ah, artinya melihat, memperhatikan atau mempedulikan. Ketika umat-nya ditindas di Mesir, dikatakan bahwa Allah melihat, memperhatikan penderitaan itu (Kel.3 :7). Lebih tepatnya bahwa Allah turut merasakan apa yang dialami umat-Nya. Penulis Surat Ibrani 4:14-15 mengungkapkan bahwa Yesus adalah Imam Besar Agung yang telah menjadi perantara antara manusia dengan Allah. Yesus yang turut merasakan apa yang diderita manusia tidak sama dengan imam besar di Israel selama ini. Tuhan Allah tetap setia memelihara segala ciptaan-Nya. Rasul Paulus menuliskan kita tahu sekarang bahwa Allah turut bekerja dalam segala sesuatu untuk mendatangkan

\footnotetext{
${ }^{15}$ Donald Guthrie, Teologi Perjanjian Baru 1, (Jakarta: BPK Gunung Mulia), 2013, hal.50
} 
kebaikan bagi mereka yang mengasihi Dia, yaitu bagi mereka yang terpanggil sesuai dengan rencana Allah (Rm 8:28). Dengan demikian, tindakan pemeliharaan Allah bukan berarti umat-Nya tidak mengalami penderitaan, kesulitan, penyakit dan kematian, melainkan Dia mendatangkan berbagai-bagai kebaikan dengan menguatkan iman serta memberi jalan keluar agar orang percaya tidak putus asa. Edukasi ini sangat penting disampaikan dalam keluarga Kristen sehingga umat-Nya tetap setia mengiring Tuhan sepanjang akhir hayat serta selama mereka hidup menguatkan sesama, merawat ciptaan dan bermafaat bagi lingkungannya.

\section{Memahami Hakikat Allah Maha Pengasih}

Sekalipun adalah Allah pengasih dan penyayang, tetapi Dia juga pemurka terhadap orang yang melanggar titah-Nya (Kel 20:5; Ul 3:26; 4:21). Murka Allah digambarkan menyala-nyala bagi pemimpin umat-Nya, mereka yang kawin campur dengan bangsa asing dan kejahatan lainnya (Ezra 10:14; 2 Taw 28:11; Maz 69:25). Umat Israel dan para pemimpin mereka mengetahui kewajiban mereka mematuhi hukum Musa (Taurat) menaati ketetapan-ketetapan, perintah-perintah dan peraturan Allah supaya mereka beruntung dalam segala yang mereka lakukan dan mereka tuju ${ }^{16}$. Pembuangan bangsa Israel ke Babel sebagai bukti kemurkaan-Nya karena umat-Nya tidak setia. Namun, kasih Allah melebihi murka-Nya. Ia memulihkan dan mengumpulkan mereka dari pembuangan dengan cara-Nya sendiri setelah mereka bertobat (Ul 30:1-10). Oleh karena itu, Allah digambarkan seperti bapa sayang kepada anak-anaknya, demikian Tuhan sayang kepada orang-orang yang takut akan Dia (Maz 103). Hakikat Allah yang pengasih dan penyayang dijelaskan bagaikan hubungan bapa dengan anak-anaknya. Secara teologi dapat dikatakan bahwa kemarahan Allah kepada umat-Nya sebagai bukti kasih-Nya, Dia bukan pedendam melainkan tidak dilakukan-Nya kepada kita setimpal dengan dosa kita dan tidak dibalas-Nya kepada kita setimpal denga kesalahan kita, tetapi setinggi langit di atas bumi, demikian besarnya kasih setia-Nya atas orang-orang yang takut akan Dia.

Hakikat Allah yang pengasih dan penyayang, Yesus menyapa-Nya sebagai Bapa sebagaimana dikenal dalam Doa Bapa kami (Mat 6:9-13) untuk mengungkapkan hubungan istimewa dengan orang-orang percaya sebagai anak Allah yang telah ditebus-Nya (Yoh 1:12). Kata Yunani "Abba” yang berasal dari bahasa Aram menunjukkan hubungan ayah dengan anak kecil. Artinya semakin diperluas dalam pemakaian sehari-hari, kira-kira artinya sama dengan 'bapa yang kekasih' ${ }^{17}$. Sebab karya Allah yang Maha Kasih, maka semua orang percaya berhak memanggil Allah sebagai Bapa, Ia menunjukkan kasih-Nya dengan mengampuni segala dosa umat-Nya. Marilah, baiklah kita berperkara, firman Tuhan, sekalipun dosamu merah seperti kain kirmizi, akan menjadi putih seperti salju, sekalipun berwarna merah seperti kain kesumba, akan menjadi putih seperti bulu domba (Yes 1:18). Hal ini berlaku bagi mereka yang mengakui dosanya (1 Yoh 1:9). Dengan demikian, Allah adalah pengasih, penyayang, penuh ketulusan serta mengasihi semua orang. Kasih Allah telah dinyatakan melalui kehadiran-Nya dalam Krisus Yesus yang mati di kayu salib sebagai puncak kasih-Nya bagi dunia (Yoh 3:16). Kasih yang diajarkan dan dipraktikan Yesus tidak mementingkan keakuan, melainkan memikirkan kepentingan orang lain tanpa syarat dan batas itulah kasih agape, kasih yang murni tanpa mengharapkan balasan atas segala pengorbanan yang Dia lakukan (Unconditional Love)"18. Edukasi nilai-nilai teologi berdasarkan kasih Allah yang telah dinyatakan dalam pelayanan Yesus bahwa marilah kita saling mengasihi, sebab kasih itu berasal dari Allah dan setiap orang yang mengasihi lahir dari Allah dan mengenal Allah. Barangsiapa tidak mengasihi ia tidak mengenal

\footnotetext{
${ }^{16}$ Walter C.Kaiser, Teologi Perjanjian Lama, (Malang: Gandum Mas), 2013, hal. 164

${ }^{17}$ Donald Guthrie, Teologi Perjanjian Baru 1, (Jakarta: BPK Gunung Mulia), 2013, hal.55

${ }^{18}$ Ibelala Gea, Kepemimpinan Yesus Teladan Pemimpin Masa Kini, Voice of Wesley: Jurnal Ilmiah Musik dan Agama, Vol. 3 No. 2, Mei 2020, hal.32
} 
Allah, sebab Allah adalah kasih (1 Yoh 4:7-8) menjadi penting ditanamkan sejak dini kepada anak-anak sehingga mereka mampu menerima berbagai perbedaan dari kemajemukan di Indonesia. Sekalipun berbeda agama, mereka menghargai nilai kemanusiaan, sebab manusia adalah ciptaan Allah.

\section{KESIMPULAN}

Radikalisme agama dipicu oleh dangkalnya pemahaman dan kesalahan interpretasi terhadap Kitab Suci serta lemahnya peran edukasi teologi dalam keluarga sebagai edukator utama dan pertama. Penggunaan ayat-ayat Kitab Suci tanpa interpretasi yang standar dan terukur menurut kaidah pemahaman secara baik dan benar cenderung menanamkan pemahaman anti terhadap keyakinan orang lain dan membentuk mindset ekslusivisme mengabaikan inklusivisme, melahirkan insan intoleran serta menolak toleransi. Keluarga sebagai edukator utama dan pertama sudah saatnya dan belum terlambat melakukan peran mendidik serta mengajarkan pokok-pokok penting teologi dalam keluarga dan bukan menyerahkan tugas ini kepada pihak lain. Dalam mini riset yang dituangkan pada artikel ini diusulkan 5 (lima) konten edukasi teologi yang representatif untuk diajarkan dalam keluarga sebagai pondasi preventif radikalisme, yakni (1) Mengedukasi anak memahami Kitab suci dengan baik dan benar; (2) Memahami hakikat Tuhan yang Esa; (3) Memahami hakikat Tuhan sebagai penyelamat, (4) Memahami hakikat Tuhan sebagai pemelihara; dan (5) Memahami hakikat Tuhan sebagai pengasih dan penyayang. Dengan demikian, sekalipun terdapat perbedaan agama, jika dihayati dan diamalkan hakikat Allah yang mengasihi seluruh manusia dan ciptaan lainnya, dapat menuntun anak bangsa Indonesia yang majemuk ini untuk hidup rukun, menerima perbedaan sebagai anugrah Tuhan, kebhinekaan tetap terawat dengan baik demi kemajuan bangsa dan negara Indonesia.

Sudah waktunya merefleksikan isi pidato Presiden pertama Indonesia, Ir. Soekarno bahwa kalau jadi Hindu jangan jadi orang India, kalau jadi Islam jangan jadi orang Arab, kalau jadi Kristen jangan jadi orang Yahudi, tetaplah jadi orang Nusantara dengan adat budaya Nusantara dengan tidak egoisme Agama ${ }^{19}$. Ledakan Bonus demografis Indonesia tahun 2020-2035 merupakan jendela peluang untuk mengelola 'bom' demografi dalam rangka menyongsong Indonesia Emas 2045. Jika peluang ini dikelola dengan baik, maka akan mendapatkan generasi yang produktif sebagai berkat bagi bangsa ini. Apabila peluang ini diabaikan, maka generasi akan menjadi beban bangsa ${ }^{20}$. Salah satu langkah strategis dalam mengelola bonus demografi anak bangsa ialah melalui edukasi teologi dalam keluarga guna mempersiapkan generasi bangsa yang dapat menerima dan menghargai perbedaan sebagai preventif gerakan radikalisme.

\footnotetext{
${ }^{19}$ John A.Titaley, Antara Tuntutan Agama dan Rasa Kemanusiaan Indonesia, (Direktorat Jenderal Bimas Kristen Kementerian Agama Republik Indonesia: Mozaik Moderasi beragama dalam Perspektif Kristen, BPK Gunung Mulia, Jakarta), 2018, hal.15

${ }^{20}$ Indras Moro, Yoel. M, Tornado Gregorius Silitonga, Penyunting, Tim KTAK Anak Bersinar Bangsa Gemilang jaringan peduli Anak bangsa, Teologi Anak: Sebuah Kajian, (Jakarta: Literatur Perkantas), 2018, hal. 26-27
} 


\section{DAFTAR PUSTAKA}

Guthrie, Donald. 2013. Teologi Perjanjian Baru 1. Jakarta: BPK Gunung Mulia

Hadiwijono, Harun. 2018. Iman Kristen. Jakarta: BPK Gunung Mulia

Kaiser, Walter C. 2013. Teologi Perjanjian Lama. Malang: Gandum Mas

Moro, Indras, dkk (Penyunting, Tim KTAK Anak Bersinar Bangsa Gemilang Jaringan Peduli Anak

Bangsa). 2018. Teologi Anak: Sebuah Kajian. Jakarta: Literatur Perkantas.

Morris, Leon. 2014. Teologi Perjanjian Baru. Malang: Gandum Mas.

Ryrie, Charles C. 2010. Teologi Dasar: Panduan Populer Untuk Memahami Kebenaran Alkitab.

Yogyakarta: Yayasan Andi.

Sabdono, Erastus. 2014. Bunga Rampai Moving To The Next Level: Akselarasi Mutu Perguruan Tinggi

Keagamaan Kristen di Indonesia. Rehobot Ministry bersama dengan BMPTKKI dan Ditjen Bimas Kristen RI.

Sugiyono, 2011. Metode Penelitian: Kuantitatif, Kualitatif dan R\&D. Bandung: Alfabeta.

Titaley, John A. 2018. Antara Tuntutan Agama dan Rasa Kemanusiaan Indonesia. Direktorat Jenderal

Bimas Kristen Kementerian Agama Republik Indonesia: Mozaik Moderasi beragama dalam Perspektif Kristen, BPK Gunung Mulia, Jakarta.

Waid, Abdul. 2013. Menguak Cara Belajar Orang Yahudi, Yogyakarta: DIVA Press.

Jurnal:

Angel Damayanti, Radikalisme Pada Komunitas Non-Islam, Repository Universitas Kristen Indonesia, 2018.

Dylfard Edward Pandey, Allah Tritunggal: Sebuah Risalah Teologis Alkitabiah tentang Keesaan dan Ketritunggalan Allah, Davar: Jurnal Teologi Vol. 1 No.1, 2020

Ibelala Gea, Kepemimpinan Yesus Teladan Pemimpin Masa Kini, Voice of Wesley: Jurnal Ilmiah Musik dan Agama, Vol. 3 No. 2, Mei 2020.

\section{Disertasi:}

Ibelala Gea, Implementasi Pembaharuan Pelaksanaan Pesta Perkawinan Adat Suku Nias Berbasis Teologi Kristen. Program Studi Doktor Teologi IAKN Tarutung, 2020.

\section{Sumber Lain:}

- $\quad$ www.republika.co.id/berita/qklu9t328/insiden-sigi-serangan-serius-terhadap-kebebasan-beragama

- www.pikiran-rakyat.com/nasional/pr-011031748/kelompok-mit-diduga-dalang-teror-di-sigi-satgastinombala-tolonglah-masyarakat-jangan-bantu-mereka

- $\quad$ www.majelismujahidin.com/about/karakteristik-majelis-mujahidin

- Surat Kabar Sinar Indonesia Baru (SIB) terbit Senin, 18 Januari 2021 